\title{
Susceptibility of Anthonomus grandis (Cotton Boll Weevil) and Spodoptera frugiperda (Fall Armyworm) to a Cry1 Ia-type Toxin from a Brazilian Bacillus thuringiensis Strain
}

\author{
Maria Fatima Grossi-de-Sa, ${ }^{1,4}$, , Mariana Quezado de Magalhães ${ }^{1,2}$, Marilia Santos Silva ${ }^{3}$, Shirley Margareth.Buffon Silva ${ }^{1}$, \\ Simoni Campos Dias ${ }^{1,4}$, Erich Yukio Tempel Nakasu ${ }^{2}$, Patrícia Sanglard Felipe Brunetta ${ }^{1,4}$, Gustavo Ramos Oliveira ${ }^{2}$, \\ Osmundo Brilhante de Oliveira Neto ${ }^{1,4,5}$, Raquel Sampaio de Oliveira ${ }^{1,4}$, Luís Henrique Barros Soares ${ }^{2}$, \\ Marco Antônio Zachia Ayub ${ }^{2}$, Herbert Alvaro Abreu Siqueira ${ }^{1}$ and Edson L.Z. Figueira ${ }^{1}$ \\ ${ }^{1}$ Embrapa Recursos Genéticos e Biotecnologia, PqEB- Final W5, Brasília - DF, Brazil \\ ${ }^{2}$ UFRGS, Universidade Federal do Rio Grande do Sul, Porto Alegre - RS, Brazil \\ ${ }^{3}$ Embrapa Cerrados, BR 020, Km 18, P. O. Box 08223, Planaltina - DF, Brazil \\ ${ }^{4}$ Pós-Graduação em Ciências Genômicas e Biotecnologia, Universidade Católica de Brasília, Brasília - DF, Brazil \\ ${ }^{5}$ UNIEURO,Brasília - DF, Brazil
}

Received 30 January 2007, Accepted 7 May 2007

\begin{abstract}
Different isolates of the soil bacterium Bacillus thuringiensis produce multiple crystal (Cry) proteins toxic to a variety of insects, nematodes and protozoans. These insecticidal Cry toxins are known to be active against specific insect orders, being harmless to mammals, birds, amphibians, and reptiles. Due to these characteristics, genes encoding several Cry toxins have been engineered in order to be expressed by a variety of crop plants to control insectpests. The cotton boll weevil, Anthonomus grandis, and the fall armyworm, Spodoptera frugiperda, are the major economically devastating pests of cotton crop in Brazil, causing severe losses, mainly due to their endophytic habit, which results in damages to the cotton boll and floral bud structures. A cry1Ia-type gene, designated cry1Ia12, was isolated and cloned from the $B t \mathbf{S 8 1 1}$ strain. Nucleotide sequencing of the cryIIa12 gene revealed an open reading frame of $2160 \mathrm{bp}$, encoding a protein of 719 amino acid residues in length, with a predicted molecular mass of 81 kDa. The amino acid sequence of Cry1Ia12 is 99\% identical to the known Cry1Ia proteins and differs from them only in one or two amino acid residues positioned along the three domains involved in the insecticidal activity of the toxin. The recombinant Cry1Ia12 protein, corresponding to the cry1Ia12 gene expressed in Escherichia coli cells, showed moderate toxicity towards first instar larvae of both cotton boll weevil and fall armyworm. The highest concentration of the recombinant Cry1Ia12 tested to
\end{abstract}

* To whom correspondence should be addressed.

Tel: 55-61-3448-4705; Fax: 55-61-3340-3624

E-mail: fatimasa@cenargen.embrapa.br achieve the maximum toxicities against cotton boll weevil larvae and fall armyworm larvae were $230 \mu \mathrm{g} / \mathrm{mL}$ and $5 \mu \mathrm{g} / \mathrm{mL}$, respectively. The herein demonstrated insecticidal activity of the recombinant Cry1Ia12 toxin against cotton boll weevil and fall armyworm larvae opens promising perspectives for the genetic engineering of cotton crop resistant to both these devastating pests in Brazil.

Keywords: Anthonomus grandis, Bt toxin, Coleoptera, Cotton, Cry1Ia, E. coli expression, Lepidoptera, Spodoptera frugiperda

\section{Introduction}

Bacillus thuringiensis (Bt), a well-known entomopathogen, is a Gram-positive spore-forming bacterium, which forms parasporal crystal (Cry) protein inclusions during the stationary growth phase (Bravo et al., 1998; Schnepf et al., 1998). These crystal inclusions are produced by one or more insecticidal proteins, which can exhibit toxicity and specificity toward a select group of Lepidopteran, Coleopteran and Dipteran insect species. The crystals are solubilized by the alkaline conditions existing in the midgut lumen of susceptible insect larvae, releasing Cry protoxins, which are enzymatically processed and converted into active Cry toxins (de Maagd et al., 2003). After activation the toxins interact with specific cell surface docking molecules and destroy the brush border membrane integrity by pore formation. These pores disrupt the osmotic regulation of the insect intestinal epithelium resulting in cell 
swelling, eventual cell lysis and insect death (Hofmann et al., 1988; Schwartz et al., 1993; Knowles, 1994).

Microbial insecticide formulations based on $B t$ are used worldwide as biopesticides and different cry genes encoding toxic Cry proteins showed great potential in the control of several economically devastating insect-pests when bioengineered in crop plants (Betz et al., 2000; Chattopadhyay et al., 2004). To date, many plant species have been genetically modified with cry genes, resulting in transgenic plants with high level of resistance to insect pests (Hilder and Boulter, 1999; Van Rie, 2000; Christou et al., 2006).

The cotton boll weevil, Anthonomus grandis (Coleoptera: Curculionidae), and the fall armyworm, Spodoptera frugiperda (Lepidoptera: Noctuidae), are devastating cotton pests responsible for more than $50 \%$ of insecticide costs in Brazilian cotton crop fields. Moreover, the endophytic habit of the A. grandis larvae inside floral buds results in destruction of the fiber quality, hampers the chemical control, causing considerable yield losses (Haynes et al., 1992). The most promising costeffective and sustainable method to control cotton boll weevil is the development of genetically resistant cotton lines that suppress the insect larval development.

Bacillus thuringiensis $\mathrm{S} 811$ is a novel Brazilian soil isolated strain, with toxicity against Lepidoptera and Coleoptera, including $S$. frugiperda and A. grandis insect-pests (Martins et al., 2005a; Quezado, 2006). Among c.a. 40 Cryl-type proteins described to date in "The Bacillus thuringiensis Toxin Specificity Database" (http://www.glfc.cfs.nrcan.gc.ca/science/research/ netintro99_e.html), the majority of them is active against Lepidoptera species, whereas few reports have shown that Cryl-type proteins are also toxic against Coleopteran species. Tailor et al. (1992) showed that the formally designated Cry5 toxin, presently designated as Cry1 Ia1 toxin (Crickmore et al., 1998), is toxic to both Lepidoptera and Coleoptera. In respect to Spodoptera species, Spodoptera litura has been shown to be susceptible to a Cry1Ia-type protein (Sasaki et al., 1996).

Searching for novel sources of cry genes encoding new Cry toxins active against cotton insect-pests important within Brazil, a crylla-type gene was isolated from the Brazilian S811 Bt strain. Herein, we report the cloning and characterization of the crylIal2 gene, its expression in E. coli cells and also its insecticidal specificities and activities towards both $A$. grandis and $S$. frugiperda cotton insect-pests.

\section{Materials and Methods}

Bacteria strain. The B. thuringiensis S811 Brazilian strain obtained from Embrapa Genetic Resources and Biotechnology collection (Bt germoplasm bank, Brasília, Brazil- http://sicol.cria.org.br/crb/BGB) was used for to isolate the cryllal2 gene. This strain was selected based on its toxicity towards cotton boll weevil (A. grandis), determined through selective bioassay (Quezado, 2006).

Isolation of a cry $1 I$ gene from the B. thuringiensis strain $\mathbf{S 8 1 1 .}$ B. thuringiensis strain $\mathrm{S} 811$ cells, grown in $30 \mathrm{~mL}$ of NYSM medium $\left(0.8 \%\right.$ nutritive broth, $0.1 \%$ yeast extract, $0.1 \% \mathrm{KH}_{2} \mathrm{PO}_{4}$, $0.01 \% \mathrm{CaCO}_{3}, 0.01 \% \mathrm{MgSO}_{4} \cdot 7 \mathrm{H}_{2} \mathrm{O}, 0.001 \% \mathrm{FeSO}_{4} \cdot 7 \mathrm{H}_{2} \mathrm{O}, 0.001 \%$ $\mathrm{MnSO}_{4} \cdot 7 \mathrm{H}_{2} \mathrm{O}$ and $0.001 \% \mathrm{ZnSO}_{4} \cdot 7 \mathrm{H}_{2} \mathrm{O}, \mathrm{pH} 7.0$ ) for $12 \mathrm{~h}$ at 200 $\mathrm{rpm}$ and $30^{\circ} \mathrm{C}$, were centrifuged and the pellets were kept at $-20^{\circ} \mathrm{C}$ for DNA extraction. The CTAB (cationic hexadecyl trimethyl ammonium bromide) method (Doyle and Doyle, 1987) was used for total DNA isolation from the B. thuringiensis strain $\mathrm{S} 811$ cells. Polymerase Chain Reaction (PCR) using a general primer set to detect cryl genes was used to detect cryl-type genes within the $B$. thuringiensis strain S811 total DNA (Ceron et al., 1995, Bravo et al., 1998). In order to identify cryll-type genes among the cryltype genes detected in B. thuringiensis strain S811 total DNA, primers to amplify complete cryll-type genes (i.e. from the start codon till the stop codon) were designed on the basis of multiple alignment of all previously described cry $1 I$ and the consensus sequences of their $\mathrm{N}$ - and $\mathrm{C}$-terminal coding regions. PCR were performed using these primers designed to amplify complete cry $1 I$ genes (forward primer: 5'-ATGAAACTAAAGAATCAAGATAAG C-3', reverse primer 5'-CTAGATGTTACGCTCAATATGG-3'), 30 cycles of amplification at $42^{\circ} \mathrm{C}$ annealing temperature and high fidelity Taq DNA polymerase (Invitrogen). The resulting PCR fragment was excised from the gel and purified using the Geneclean $^{\circledR}$ II Kit (Q-BIOGene), following the manufacturer's instruction.

The complete crylIal2 gene sequence was amplified and cloned using specific forward 5'-ATGAAACTAAAGAATCAAGATAA GC-3' and reverse 5'-CTAGATGTTACGCTCAATATGG-3' PCR primers, designed on the basis of highly conserved $\mathrm{N}$-terminal and C-terminal coding regions after alignment of all previously described $c r y l I$ sequences.

Cloning, sequencing and sequence analysis of the crylla12 gene from the B. thuringiensis strain S811. The purified PCR fragment putatively corresponding to a $B$. thuringiensis strain $\mathrm{S} 811$ cry $1 I$ gene was cloned into the pGEM-T Easy vector (Promega, Maldison, WI, USA) and used to transform E. coli XL1 Blue cells. The clone was sequenced using an ABI 3700 automated sequence analyzer (Applied Biosystem Perkin Elmer). Computer analyses of the cloned DNA sequence were done using the GCG software package (Genetics Computer Group, University of Wisconsin). Databank comparisons of the cloned DNA sequence with other published cry sequences were made using the BLASTx software from the NCBI databank (http://www.ncbi.nlm.nih.gov). The Conserved Domain Database search (CDD-search) from the NCBI site was used to compare motif identity and similarity with the clone DNA sequence and known conserved domains. Sequence alignments and dendrograms were obtained by using CLUSTAL W software and were edited with the BOXSHADE software (http:// www.ch.embnet.org/software/BOX_form). Dendrograms were edited using the TreeView software (http://darwin.zoology.gla.ac.uk/ $\sim$ rpage/treeviewx). The molecular mass and predicted $p I$ of the clone deduced protein sequences were determined by the Protein Machine software available at the EXPASY site (http://us.expasy. org/tools/). The clone reported here was identified as a novel cryl Ia gene from the $B$. thuringiensis strain $\mathrm{S} 811$ and was named crylla12. The sequence of the crylla12 gene was submitted to the GeneBank, being AY788868 the assigned accession number. 
Construction of $E$. coli expression vector pET101-cry1Ia12. $E$. coli XL1 Blue cells containing the crylIal2 gene cloned into the pGEM-T Easy vector were grown in Luria-Bertani (LB) medium in the presence of $100 \mu \mathrm{g} / \mathrm{mL}$ ampicillin, for $14-16 \mathrm{~h}$ at $37^{\circ} \mathrm{C}$ and the plasmid DNA was isolated using the chloroform: isoamyl alcohol method (Sambrook et al., 2001). PCR was performed using the isolated plasmid as template, the forward primer 5'-CACCATGAA ACTAAAGAATCAAGATAAGC-3', the reverse primer 5'-TTCTG CCTCATATGTTACTTCTACC-3', 30 cycles of amplification at $50^{\circ} \mathrm{C}$ annealing temperature and high fidelity Taq DNA polymerase (Invitrogen). The resulting PCR fragment was excised from the gel and purified using the Geneclean ${ }^{\circledR}$ II Kit (Q-BIOGene), following the manufacturer's instruction. The purified PCR fragment was subcloned into the expression vector pET101 D-TOPO (Invitrogen), following the manufacturer's instructions. The resulting construction, encoding the recombinant cryllal2 gene to be expressed fused to a C-terminal His-tag, was named pET101-cryl Ia12.

Recombinant Cry1Ia12 toxin expression and purification. $E$. coli BL21 Star (DE3) cells transformed with pET101-crylla12 were grown at $37^{\circ} \mathrm{C}$ in $2 \mathrm{~L}$ erlenmeyer flasks containing $500 \mathrm{~mL}$ of LB medium, at $200 \mathrm{rpm}$ agitation, in the presence of $200 \mu \mathrm{g} / \mathrm{mL}$ ampicillin, until O.D. ${ }_{600}=0.6-0.8$. Cry1Ia12 expression was induced by addition of $1 \mathrm{mM}$ isopropyl-beta-D-thiogalactopyranoside (IPTG) when an O.D. ${ }_{600}=0.7$ was reached. Alternatively, the expression of recombinant His-tagged Cry1Ia12 was increased by cultivating the recombinant $E$. coli in a $5.0 \mathrm{~L}$ BBraun Biostat $\mathrm{C}$ bioreactor, and by using $20 \mathrm{~g} / \mathrm{L}$ lactose for recombinant protein induction. Sixteen hours after induction the cells were harvested by centrifugation at $4,000 \mathrm{rpm}$. The pellet containing the cells expressing the Cry $1 \mathrm{Ia} 12$ His-tagged protein was then resuspended in Lysis buffer $(50 \mathrm{mM}$ Sodium Phosphate buffer, $300 \mathrm{mM} \mathrm{NaCl}, 1 \%$ Glycerol and $0.5 \%$ Triton X-100, pH 7.0). The crude extract was sonicated three times for $5 \mathrm{~min}$ (large tip, Virsonic Cell Disrupter -Model 16-850), centrifuged at $10,000 \mathrm{rpm}$ for $20 \mathrm{~min}$ at $4^{\circ} \mathrm{C}$ and the supernatant was analyzed in a $12 \%$ SDS-PAGE (Laemmli et al., 1970). The supernatant was also used for the partial purification of the recombinant Cry1Ia12 using $\mathrm{Ni}^{2+}$ nitrilo-triacetic acid affinity resin (Ni-NTA, QIAGEN) equilibrated with Equilibration buffer (50 mM Sodium Phosphate buffer, $300 \mathrm{mM} \mathrm{NaCl}, 10 \mathrm{mM}$ Imidazole $\mathrm{pH}$ 7.0). The supernatant mentioned, containing the E. coli expressed recombinant Cry1Ia12 His-tagged protein, was incubated for 30 min within the equilibrated column. The column was then washed with two different buffers: first with $100 \mathrm{~mL}$ of Equilibration buffer and then $100 \mathrm{~mL}$ of the same buffer containing $2 \mathrm{mM}$ Imidazole. The recombinant Cry1Ia12 His-tagged protein was eluted with $6 \mathrm{~mL}$ of Equilibration buffer containing $250 \mathrm{mM}$ of Imidazole. All the steps were done using a flow rate of $2 \mathrm{~mL} / \mathrm{min}$. The eluted protein was dialyzed against $50 \mathrm{mM}$ sodium carbonate buffer $\mathrm{pH}$ 10.5 and stored at $4^{\circ} \mathrm{C}$. The purified protein was quantified according to the Lowry method (Lowry et al., 1951).

Bioassays of the recombinant Cry1Ia12 toxicity against insect larvae. Bioassays of the recombinant Cry $1 \mathrm{Ia} 12$ toxicity against cotton boll weevil larvae were carried out in $40 \mathrm{~mL}$ of sterilized artificial diet as described by Monnerat et al. (2000). The recombinant Cry1Ia12 protein, purified and dialyzed as explained before, was incorporated in the diet at final concentrations of $50 \mu \mathrm{g} /$
$\mathrm{mL}, 100 \mu \mathrm{g} / \mathrm{mL}$ and $230 \mu \mathrm{g} / \mathrm{mL}$, respectively. The diet was added to Petri dishes and neonate larvae were placed in pits created in the artificial diet. After 7 days of incubation at $28^{\circ} \mathrm{C} \pm 2,55 \% \pm 5$ relative humidity and photoperiod of $14 \mathrm{~h}$, the dead larvae were counted. In the negative control treatment, distilled water and dialysis buffer $(50 \mathrm{mM}$ sodium carbonate buffer $\mathrm{pH} 10.5)$ were added to the artificial diet. Each treatment was repeated four times and each replicate contained 15 larvae. For S. frugiperda, freshly prepared artificial diet, free of sorbic acid, nipagin and formaldehyde, at $50^{\circ} \mathrm{C}$, was poured into a 24 -well cell culture plate. After solidification, the recombinant CrylIa12 protein, purified and dialyzed, was applied on the diet surface in each well and allowed to dry. Subsequently, an 1-day-old second instar larva of $S$. frugiperda was added to each well. In the negative control treatment, distilled water and dialysis buffer $(50 \mathrm{mM}$ sodium carbonate buffer $\mathrm{pH} 10.5$ ) were added to the artificial diet. Twentyfour larvae and one negative control were tested. The plates were covered with acrylic lids and incubated at the same conditions used for rearing the insects. After $48 \mathrm{~h}$, the surviving larvae were individually transferred to $50 \mathrm{~mL}$ cups containing rearing diet and the mortality was assessed. Larval mortality was assessed again at day 5 (Praça et al., 2004). To calculate the mortality value, decimal serial dilutions of the protein were made. Five dilutions of the protein and 24 larvae per dilution were tested, following the same procedure above mentioned. The bioassays were repeated three times with twenty-four larvae and one negative control. Mortality data were analyzed and calculated.

\section{Results}

Cloning and sequence analyses of the cry1Ia12 gene. PCR of cryl-type genes using a set general primers resulted in amplification of a $0.3-\mathrm{kb}$ fragment, indicating the presence of a cryl-type gene in the B. thuringiensis S811 strain (data not shown). Further PCR with primers specifically designed to detect $c r y 1$-type genes, among the previously detected cryltype genes found within the genome of the $B$. thuringiensis S811 strain, resulted in the amplification of a fragment of approximately 2200 bp (data not shown). This putative $c r y l I-$ type gene was cloned into the vector pGEMT-easy, and sequencing analysis revealed a high nucleotide sequence similarity of the insert with crylla sequences previously reported (data not shown). This sequence was designated cryllal2 gene, since other 11 crylla genes (cryllal till cry 1Iall) are already described in public sequence databases. The cryllal2 gene comprised a 2160 bp open reading frame encoding a predicted protein of 719 amino acid residues (Fig. 1) and predicted $p I$ value of 6,21. Amino acid sequence homology analyses among ten known holotypes Cry1Ia proteins indicated that the sequence of the deduced amino acid sequence of the cryllal2 gene (i.e. Cry1Ia12 protein) is $99 \%$ identical to the amino acid sequences of Cry1Ia1, Cry1Ia2, Cry1Ia3, Cry1Ia4, Cry1Ia5, Cry1la6, Cry1Ia8, Cry1Ia10 and Cry1Ia11. The amino acid sequence of Cry1Ia12 is $96 \%$ identical to the amino acid sequence of Cry1 Ia7. Concerning the amino acid sequence of other CrylI-type proteins, the 


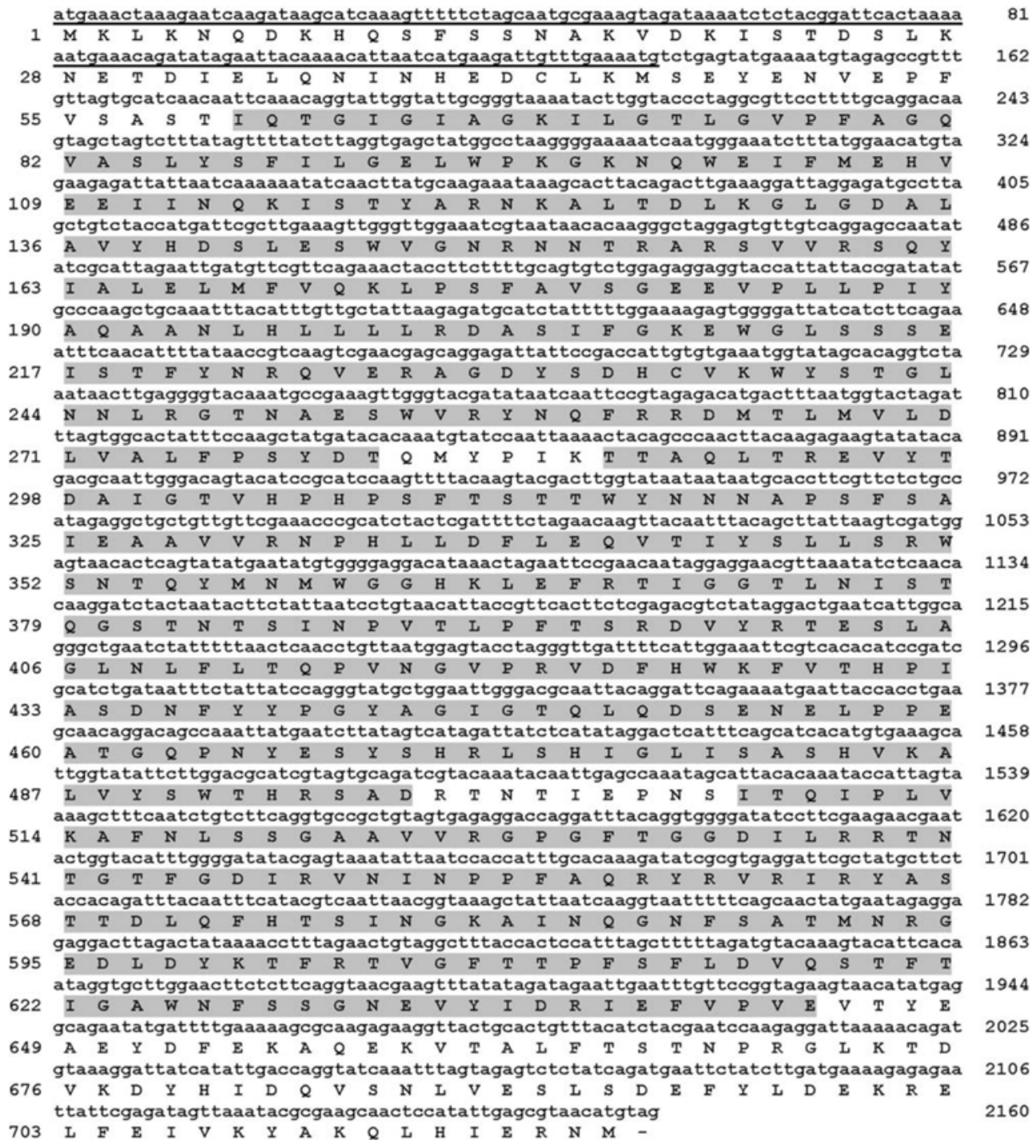

Fig. 1. Nucleotide sequence of the crylIal2 gene (GenBank accession number AY788868) and the deduced amino acid sequence of the corresponding Cry1Ia12 protein. The N-terminal sequence has been underlined. The three classic structural domains present in Cry proteins are in boldface and shaded.

amino acid sequence of Cry 1 Ia12 is $93 \%$ identical to Cry1 Ie1, $92 \%$ identical to Cry $1 \mathrm{Ib} 1$ and $89 \%$ identical to Cry1Ic1, Cry1Ic2 and Cry1Id1. Amino acid sequence alignment among Cry1I-type proteins revealed that Cry1Ia12 contains amino acid residues, which are divergent in relation to the other Cry1I-type proteins along all its three structural domains (Fig. 2). When compared with the others crylla-type genes, cryllal2 exhibits substitutions at positions 476 (a for g) and 1719 (c for t), resulting in a single replacement of the Lys ${ }^{159}$ by Arg at domain I (located at the second alpha-helix) (Fig. 1 and 2). This replacement also occurs in the crylla5 sequence (Selvapandiyan et al., 1998) in this exact position. Compared to cryllal (Tailor et al., 1992) and crylla3 (Shin et al., 1995) there was a substitution at position 697 ( $\mathrm{t}$ for $\mathrm{g}$ ), resulting in the replacement of the $\operatorname{Tyr}^{233}$ by Asp at domain I. Compared to the crylla3, cryllall and crylla5 genes there were substitutions in the cryllal 2 sequence at positions 2133 (c for $\mathrm{g})$ and 2134 ( $\mathrm{g}$ for $\mathrm{c}$ ), corresponding to the replacement of the $\mathrm{Asn}^{711}$ by Lys and of the Glu ${ }^{712}$ by Gln, both at domain III, respectively (Fig. 1 and 2). Cry1Ia7 represents an exception, since it is the most heterologous Cry1 Ia-type protein, differing from Cry1Ia12 in 28 amino acid residues, mainly localized within the Domain II (Fig. 2). Among all the CrylI-type proteins aligned with Cry1Ia12, the domain I is the most heterologous while the domain III is the most conserved one (Fig. 2).

Recombinant Cry1Ia12: $E$. coli expression, purification and evaluation of toxicity against insect larvae. The $E$. coli BL21 Star (DE3) strain harboring the pET101-crylla12 construct 


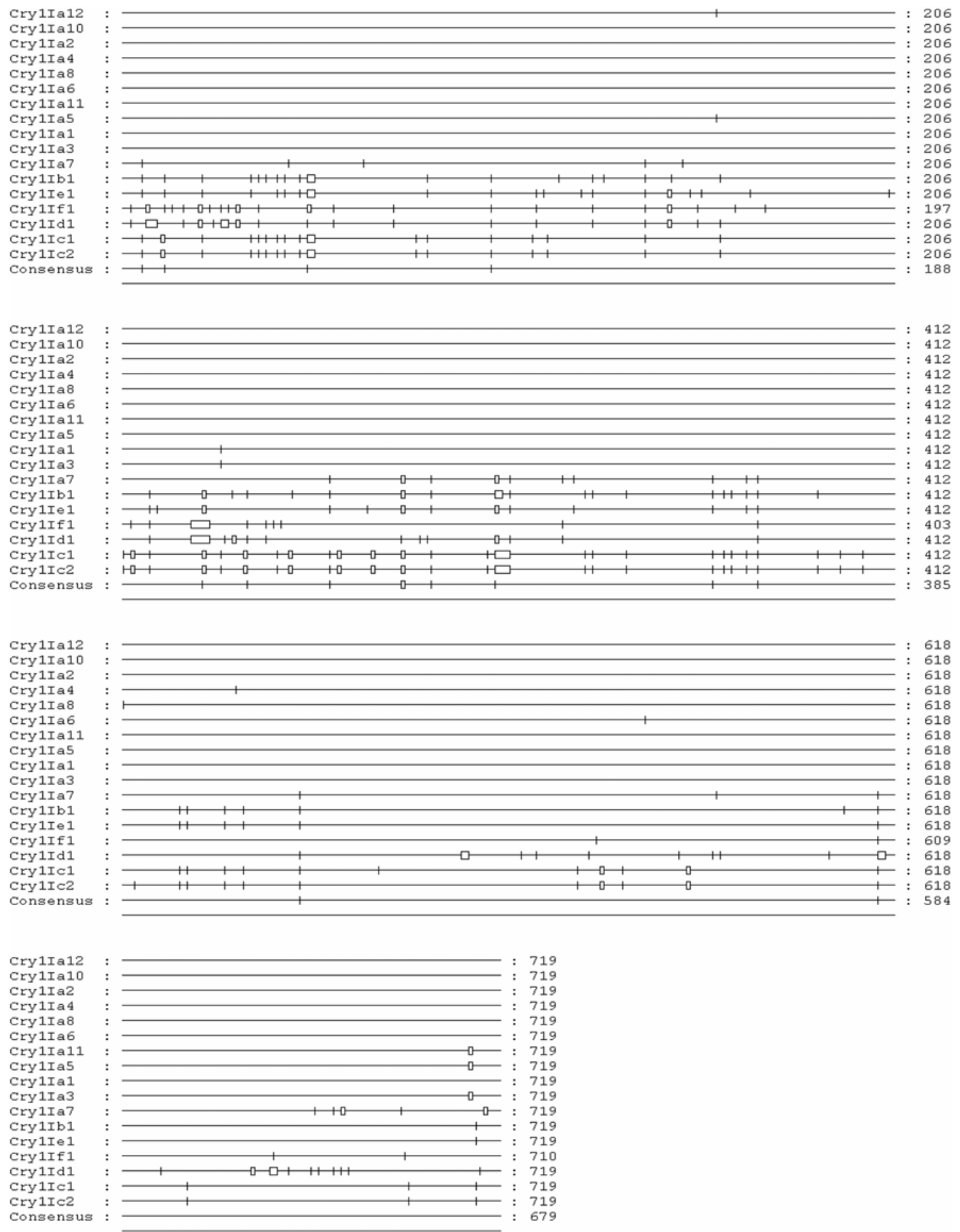

Fig. 2. Alignment comparison among the amino acid sequences of Cry1Ia12 and other Cry $1 \mathrm{I}$-type proteins. The horizontal lines represent the conserved amino acid sequence stretches among the proteins. Vertical lines and rectangles represent single amino acids and amino acid sequence stretches, respectively, which are divergent among the proteins. The three structural domains in Cry1Ia12 protein sequence are at positions 60 to 282 (Domain I), 287 to 487 (Domain II) and 507 to 644 (Domain III).

was induced with $1 \mathrm{mM}$ IPTG to express the recombinant His-tagged Cry1 Ia12 protein. SDS-PAGE analysis of E. coli extracts after IPTG induction, showed a differential protein band corresponding to the expected $74-\mathrm{kDa}$ recombinant His- 
(A)

$\begin{array}{lll}1 & 2 & 3\end{array}$

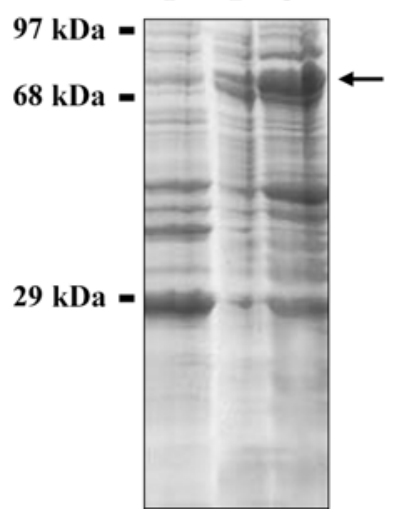

(B)

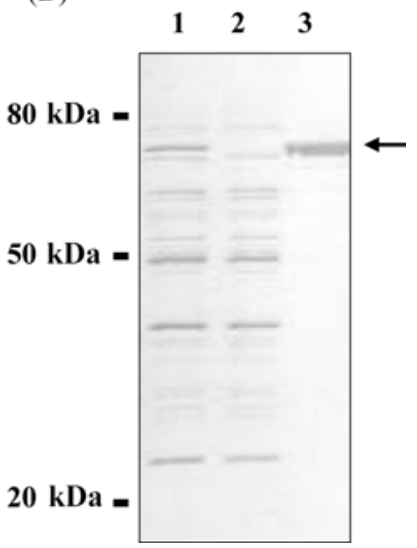

Fig. 3. (A) SDS-PAGE (12\%) analysis showing the expressed recombinant Cry $1 \mathrm{Ia} 12$ protein. Lane 1 . Non-induced $E$. coli strain BL21Star (DE) containing the expression vector without insert was used as a negative control of the expression. Lane 2. E. coli crude extract induced with $1 \mathrm{mM}$ IPTG after $6 \mathrm{~h}$ expressing recombinant Cry1Ia12 protein, sonicated and centrifuged. Lane 3. E. coli crude extract induced with $1 \mathrm{mM}$ IPTG after $12 \mathrm{~h}$ expressing recombinant CrylIa12 protein, sonicated and centrifuged. Arrows indicate the expressed 74-kDa recombinant Cry1Ia12. (B) SDS-PAGE (12\%) showing the purified recombinant CrylIa12 protein. Lane $1 . E$. coli crude extract inducted with $1 \mathrm{mM}$ IPTG after $12 \mathrm{~h}$ expressing the recombinant CrylIa12 protein. Lane 2. Fraction of E. coli crude extract (from Lane 1) which was not retained in the columm. Lane 3. Recombinant Cry1Ia12 protein purified by using Ni-NTA column. Arrow shows the expected purified $74-\mathrm{kDa}$ recombinant Cry1Ia12 protein.

tagged Cry1 Ia12 protein (Fig. 3A). No additional bands were identified within extracts of non-induced cells with empty pET101 vector (Fig. 3A). The expression conditions were

optimized to increase the yield of recombinant His-tagged Cry1la12 by cultivating the recombinant $E$. col $i$ in $5 \mathrm{~L}$ bioreactor and by using $20 \mathrm{~g} / \mathrm{L}$ lactose induction. In these conditions, a large amount of the recombinant His-tagged Cry1Ia12 protein was produced and, subsequently, purified using $\mathrm{Ni}^{2+}$-NTA affinity chromatography from sonicated $E$. coli crude extract (Fig. 3B). The toxicity of purified recombinant His-tagged Cry1la12 was tested in diet bioassays against cotton boll weevil and fall armyworm larvae. The bioassays revealed that both insect pest larvae were susceptible to the purified recombinant His-tagged Cry1Ia12 (Fig. 4). The purified recombinant His-tagged Cry1 Ia12 was toxic to A. grandis and to $S$. frugiperda larvae, being $230 \mu \mathrm{g} / \mathrm{mL}$ and $5 \mu \mathrm{g} / \mathrm{mL}$ the highest concentrations tested to achieve the maximum toxicities, respectively (Fig. 4). Additional bioassays against the same insect larvae, using different recombinant Cry proteins, including Cry3Aa, Cry1Aa, Cry1Ac, and Cry1Ba were performed (data not shown). Except for Cry1Ia12 toxin, no other tested Cry protein was significantly toxic to $A$. grandis, and no other tested Cry toxin had effect on larval growth or mortality rates.

\section{Discussion}

Here we report the isolation of a crylla-type gene from the Brazilian Bt strain S811, named cryllal2 gene, which presents marginal insecticidal activity against $A$. grandis and reasonable toxicity against $S$. frugiperda. The Cry1Ia12 protein sequence differs from the other Cry1 Ia-type proteins only in one or two amino acid residues localized along the three structural domains (I, II and III) involved with the insecticidal activity of the Cry proteins. Crylla7 is the most heterologous cryllatype gene, differing from Cry1Ia12 in 28 amino acid residues, mainly localized within the Domain II. Considering all the
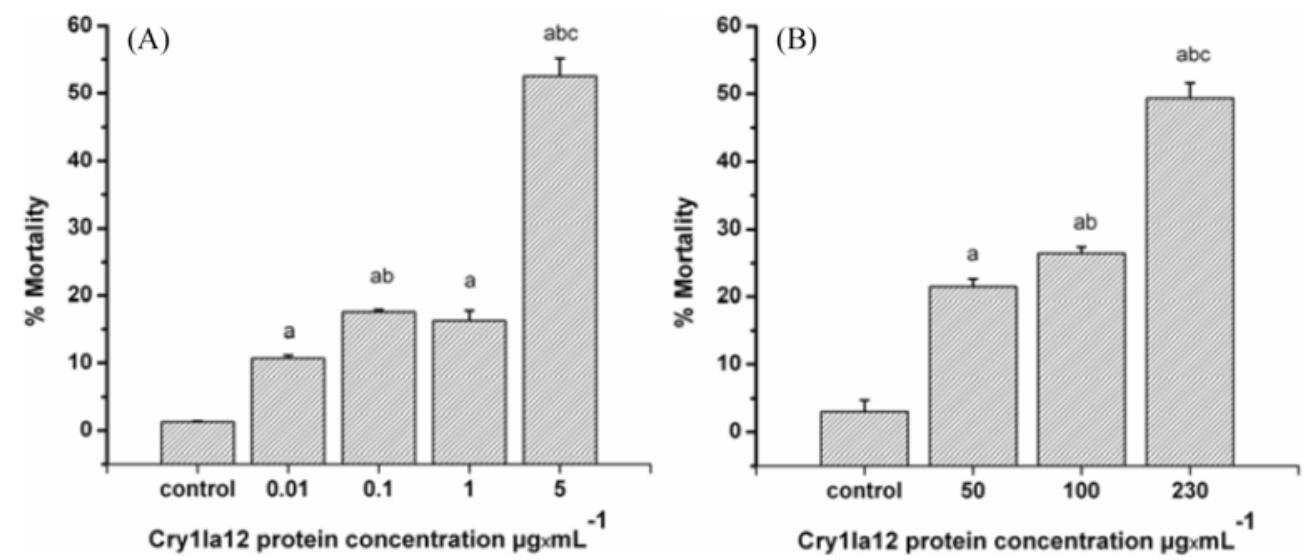

Fig. 4. Bioassays of purified recombinant His-tagged Cry $1 \mathrm{Ia} 12$ toxicity against cotton insect-pests. All bioassays were conducted three times with different amounts of recombinant CrylIa12 protein. a, b, c: means significant differences determined by the Tukey test $(p<0.05$ ). In the graphics, (a) differs from the controls at $0.05 \%$ and (c) differs from (a) and (b) at $0.05 \%$. (A) Bioassay of purified recombinant His-tagged Cry1Ia12 toxicity against $S$. frugiperda. Four concentrations of recombinant Cry1Ia12 were tested: $0.010,0.100$, 1 and $5 \mu \mathrm{g} / \mathrm{mL}$. (B) Bioassay of purified recombinant His-tagged Cry1Ia12 toxicity against $A$. grandis. Three concentrations of recombinant Cry1Ia12 were tested: 50,100 and $230 \mu \mathrm{g} / \mathrm{mL}$. 
Table 1. Insecticidal activity of various CrylI-type toxins, previously described in the literature

\begin{tabular}{|c|c|c|c|c|c|c|c|}
\hline \multicolumn{3}{|c|}{ Insect } & \multirow{2}{*}{$\begin{array}{l}\text { Cry1I-type } \\
\text { toxin }\end{array}$} & \multirow{2}{*}{$\begin{array}{l}\text { Assay } \\
\text { type } \\
\text { (a) }\end{array}$} & \multirow{2}{*}{$\begin{array}{l}\mathrm{LC}_{50} \\
\text { (d) }\end{array}$} & \multirow{2}{*}{$\begin{array}{l}\text { Active } \\
\text { (f) }\end{array}$} & \multirow{2}{*}{$\begin{array}{l}\text { Reference } \\
\text { (g) }\end{array}$} \\
\hline Order & Scientific name & Common name & & & & & \\
\hline \multirow{10}{*}{ Coleoptera } & \multirow{4}{*}{ Agelastica coerulea } & \multirow{4}{*}{ alder leaf beetle } & Cry1Ia3 & LD & $>1900 \mu \mathrm{g} / \mathrm{mL}$ & $\mathrm{N}$ & Shin et al., 1995 \\
\hline & & & Cry1Ia3 & LD & $>1900 \mu \mathrm{g} / \mathrm{mL}$ & $\mathrm{N}$ & Choi et al., 2000 \\
\hline & & & Cry1Ib1 & LD & $>2600 \mu \mathrm{g} / \mathrm{mL}$ & $\mathrm{N}$ & Shin et al., 1995 \\
\hline & & & Cry1Id1 & LD & $>960 \mu \mathrm{g} / \mathrm{mL}$ & $\mathrm{N}$ & Choi et al., 2000 \\
\hline & Diabrotica spp. & corn rootworm & Cry1Ia4 & dns & dns & $\mathrm{N}$ & Kostichka et al., 1996 \\
\hline & \multicolumn{2}{|c|}{ Leptinotarsa decemlineata Colorado potato beetle } & $\begin{array}{l}\text { Cry1Ia1 } \\
\text { Cry1Ia4 }\end{array}$ & $\begin{array}{l}\text { LD } \\
\text { dns }\end{array}$ & $\begin{array}{c}250 \mu \mathrm{g} / \mathrm{mL} \\
\mathrm{dns}\end{array}$ & $\begin{array}{l}\mathrm{Y} \\
\mathrm{N}\end{array}$ & $\begin{array}{l}\text { Tailor et al., } 1992 \\
\text { Kostichka et al., } 1996\end{array}$ \\
\hline & \multirow{2}{*}{ Phaedon brassicae } & \multirow{2}{*}{ daikon leaf beetle } & Cry1Ia3 & LD & $>1900 \mu \mathrm{g} / \mathrm{mL}$ & $\mathrm{N}$ & Shin et al., 1995 \\
\hline & & & Cry1Ib1 & LD & $>2600 \mu \mathrm{g} / \mathrm{mL}$ & $\mathrm{N}$ & Shin et al., 1995 \\
\hline & Pyrrhalta aenescens & elm leaf beetle & Cry1Ie1 & LD & dns & $\mathrm{N}$ & Song, et al., 2003 \\
\hline & Tenebrio molitor & yellow mealworm & Cry1Ia2 & DI & $>2000 \mu \mathrm{g} / \mathrm{mL}$ & $\mathrm{N}$ & Gleave et al., 1993 \\
\hline Diptera & Culex pervigilans & mosquito & Cry1Ia2 & FI & $>2000 \mu \mathrm{g} / \mathrm{mL}$ & $\mathrm{N}$ & Gleave et al., 1993 \\
\hline \multirow{30}{*}{$\begin{array}{l}\text { Lepi- } \\
\text { doptera }\end{array}$} & Artogeia rapae & imported cabbageworm & Cry1Ia3 & LD & $0.11 \mu \mathrm{g} / \mathrm{cm}^{2}$ & $\mathrm{Y}$ & Koo et al., 1995 \\
\hline & \multirow{6}{*}{ Bombyx mori } & \multirow{6}{*}{ domestic silkworm } & Cry1Ia1 & LD & $0.10-1.00 \mu \mathrm{g} / \mathrm{mL}$ (e) & $\mathrm{Y}$ & Sasaki et al., 1996 \\
\hline & & & Cry1Ia3 & DI & $10.90 \mu \mathrm{g} / \mathrm{mL}$ & $\mathrm{Y}$ & Shin et al., 1995 \\
\hline & & & Cry1Ia3 & DI & $8.70 \mu \mathrm{g} / \mathrm{cm}^{2}$ & $\mathrm{Y}$ & Koo et al., 1995 \\
\hline & & & Cry1Ia3 & DI & $7.08 \mu \mathrm{g} / \mathrm{mL}$ & $\mathrm{Y}$ & Choi et al., 2000 \\
\hline & & & Cry1Ib1 & DI & $>260 \mu \mathrm{g} / \mathrm{mL}$ & $\mathrm{N}$ & Shin et al., 1995 \\
\hline & & & Cry1Id1 & DI & $439.56 \mu \mathrm{g} / \mathrm{mL}$ & $\mathrm{Y}$ & Choi et al., 2000 \\
\hline & Epiphyas postvittana & light brown apple moth & Cry1Ia2 & DI & $67 \mu \mathrm{g} / \mathrm{mL}$ & $\mathrm{Y}$ & Gleave et al., 1993 \\
\hline & \multirow{2}{*}{ Helicoverpa armigera } & \multirow{2}{*}{ cotton boll worm } & Cry1Ia5 & IP & dns & $\mathrm{Y}$ & Selvapandiyan et al., 1998 \\
\hline & & & Cry1Ie1 & DI & dns & $\mathrm{N}$ & Song, et al., 2003 \\
\hline & Hyphantria cunea & fall webworm moth & Cry1Ia3 & DI & $>46.32 \mu \mathrm{g} / \mathrm{cm}^{2}$ & $\mathrm{~N}$ & Koo et al., 1995 \\
\hline & \multicolumn{2}{|c|}{ Leguminivora glycinivorella soybean pod borer } & Cry1Ie1 & LD & $9.02 \mu \mathrm{g} / \mathrm{mL}$ & $\mathrm{Y}$ & Song, et al., 2003 \\
\hline & \multirow{3}{*}{ Ostrinia furnacalis } & \multirow{3}{*}{ Asian corn borer } & Cry1Ie1 & DI & $2.22 \mu \mathrm{g} / \mathrm{mL}$ & $\mathrm{Y}$ & Song, et al., 2003 \\
\hline & & & Cry1Ie1 & DI (b) & $6.58 \mu \mathrm{g} / \mathrm{mL}$ & $\mathrm{Y}$ & Liu et al., 2004 \\
\hline & & & Cry1Ie1 & DI (c) & dns & $\mathrm{Y}$ & Liu et al., 2004 \\
\hline & \multirow{3}{*}{ Ostrinia nubilalis } & \multirow{3}{*}{ European corn borer } & Cry1Ia1 & DI & $16 \mu \mathrm{g} / \mathrm{mL}$ & $\mathrm{Y}$ & Tailor et al., 1992 \\
\hline & & & Cry1Ia1 & DI & $3.34 \mu \mathrm{g} / \mathrm{mL}$ & $\mathrm{Y}$ & Sekar et al., 1997 \\
\hline & & & Cry1Ia4 & dns & dns & $\mathrm{Y}$ & Kostichka et al., 1996 \\
\hline & \multirow{9}{*}{ Plutella xylostella } & \multirow{9}{*}{ diamondback moth } & Cry1Ia1 & LD & $0.001-0.01 \mu \mathrm{g} / \mathrm{mL}$ (e) & $\mathrm{Y}$ & Sasaki et al., 1996 \\
\hline & & & Cry1Ia3 & LD & $17.40 \mu \mathrm{g} / \mathrm{mL}$ & $\mathrm{Y}$ & Shin et al., 1995 \\
\hline & & & Cry1Ia3 & LD & $0.089 \mu \mathrm{g} / \mathrm{cm}^{2}$ & $\mathrm{Y}$ & Koo et al., 1995 \\
\hline & & & Cry1Ia3 & LD & $12.90 \mu \mathrm{g} / \mathrm{mL}$ & $\mathrm{Y}$ & Tabashnik et al., 1996 \\
\hline & & & Cry1Ia3 & LD & $2.57 \mu \mathrm{g} / \mathrm{mL}$ & $\mathrm{Y}$ & Choi et al., 2000 \\
\hline & & & Cry1Ia4 & dns & dns & $\mathrm{Y}$ & Kostichka et al., 1996 \\
\hline & & & Cry1Ib1 & LD & $147.80 \mu \mathrm{g} / \mathrm{mL}$ & $\mathrm{Y}$ & Shin et al., 1995 \\
\hline & & & Cry1Id1 & LD & $4.26 \mu \mathrm{g} / \mathrm{mL}$ & $\mathrm{Y}$ & Choi et al., 2000 \\
\hline & & & Cry1Ie1 & LD & $0.20 \mu \mathrm{g} / \mathrm{mL}$ & $\mathrm{Y}$ & Song, et al., 2003 \\
\hline & Snodontera exio & & Cry1Ia3 & LD & $>66 \mu \mathrm{g} / \mathrm{cm}^{2}$ & $\mathrm{~N}$ & Koo et al., 1995 \\
\hline & сарьета ехtgua & oeet anmy wom & Cry1Ie1 & DI & dns & $\mathrm{N}$ & Song, et al., 2003 \\
\hline & Spodoptera litura & tobacco cutworm & Cry1Ia1 & LD & $0.1-1.0 \mu \mathrm{g} / \mathrm{mL}$ (e) & $\mathrm{Y}$ & Sasaki et al., 1996 \\
\hline
\end{tabular}

(a) LD = leaf dip (Tabashnik et al., 1993); DI = diet incorporation (of Cry proteins expressed in E. coli, Bacillus or transgenic plant); FI = free ingestion; IP = in planta; dns = data not shown

(b) Bioassay performed with the modified CrylIa4 protein (Cryl Ia4m), encoded by a gene modified to incorporate the preferential codon usage of plants, expressed in E. coli.

(c) Cry $1 \mathrm{Ia} 4 \mathrm{~m}$ expressed in transgenic tobacco. DI assay performed as described in He et al. (2003). Journal of Economic Entomology 96, 935-940.

(d) $\mathrm{LC}_{50}=$ lethal concentration that causes $50 \%$ mortality of the insects. $\mathrm{mg} / \mathrm{mL}=\mathrm{mg}$ of Cry protein $/ \mathrm{mL}$ solid diet (in case diet incorporation bioassay) or $\mathrm{mg} / \mathrm{mL}=\mathrm{mg}$ of Cry protein/mL solution (in case of leaf dip or free ingestion bioassays), unless otherwise stated. $\mathrm{mg} / \mathrm{cm}^{2}=\mathrm{mg}$ of Cry protein/ $\mathrm{cm}^{2}$ solid diet surface (in case diet incorporation bioassay) or $\mathrm{mg} / \mathrm{cm}^{2}=\mathrm{mg}$ of Cry protein $/ \mathrm{cm}^{2}$ leaf disk surface (in case of leaf dip bioassay). dns $=$ data not shown. (e) $\mathrm{mg} / \mathrm{mL}=\mathrm{mg}$ of crystal protein $/ \mathrm{mL}$ of crystal-spore mixture.

(f) The parameter is mortality. $\mathrm{Y}=$ yes/active; $\mathrm{N}=$ no/not active.

(g) Choi et al. (2000) Current Microbiology 41, 65-69; Gleave et al. (1993) Applied and Environmental Microbiology 59, 1683-1687; Koo et al. (1995) FEMS Microbiology Letters 134, 159-164; Kostichka et al. (1996) Journal of Bacteriology 178, 2141-2144; Liu et al. (2004) In Vitro Cellular \& Developmental Biology-Animal 40, 312-317; Sasaki et al. (1996) Current Microbiology 32, 195-200; Sekar et al. (1997) Applied and Environmental Microbiology 63, 2798-2801; Selvapandiyan et al. (1998) Molecular Breeding 4, 473-478; Shin et al. (1995) Applied and Environmental Microbiology 61, 24022407; Song et al. (2003) Applied and Environmental Microbiology 69, 5207-5211; Tabashnik et al. (1996) Applied and Environmental Microbiology 62, 2839-2844; Tailor et al. (1992) Molecular Microbiology 6, 1211-1217. 
Cry1I-type proteins compared to Cry1Ia12, the domain I is the most heterologous among them while the domain III is the most conserved one. Domains II and III are believed to be involved in recognition and binding of Cry proteins to the specific receptors on the brush border apical membrane of insect midgut cells, while the domain I is involved in membrane insertion and pore formation through the insect gut epithelium (de Maagd et al., 2001). An additional role in pore formation has been proposed for Domain III (de Maagd et al., 2001). The differences in amino acid sequences found along the three domains of Cry1Ia12 as compared to other Cry1Itype proteins may reflect eventual differences in the insecticidal activity of these toxins in terms of specificity against target insects and level of toxicity.

The majority of the Cry1I-type proteins (i.e. Cry1 Ia, b, c, d, e, and f), expressed either in homologous systems (i.e. Bacillus) or in heterologous systems (i.e. E. coli; transgenic plant), exhibit activity mostly against Lepidoptera and rarely against Coleoptera (Table 1). In view of the high homologies of the Cry1Ia12 amino acid sequence to other Cry1Ia-type proteins, its activity against the Coleopteran species $A$. grandis was somewhat unexpected. Recently, another Cry protein codified by a crylla gene, isolated from another $B$. thuringiensis strain, was expressed in baculovirus system and also showed activity towards $A$. grandis and $S$. frugiperda (Martins, 2005b). Tailor et al. (1992) have also found out that the product of a crylI-type gene was toxic to larvae of the Coleoptera Leptinotarsa decimlineata (Colorado potato beetle), besides presenting toxicity to the Lepidoptera Ostrinia nubilalis.

To date, around 150 Cry toxin genes have been described in "The Bacillus thuringiensis Toxin Specificity Database" (http://www.glfc.cfs.nrcan.gc.ca/science/research/netintro99 e.html), many of them with known ability to control a great variety of insect pests, including members of Lepidoptera, Coleoptera, Diptera and Hymenoptera orders, as well as nematodes (Schnepf et al., 1998; Hilder and Boulter, 1999; de Maagd et al., 2001; de Maagd et al., 2003). The Cry3Aa1 and the $B t$ binary toxin Cry23A/Cry37 were reported to be toxic to A. grandis (Hernstadt et al., 1986; Donovan and Slaney, 2000). Nevertheless, except for the herein reported Cry1 Ia12 toxin, to our knowledge none of the around 40 different Cry1type toxins described to date were demonstrated be toxic to $A$. grandis. The maximum concentration tested to achieve the maximum toxicity $(230 \mu \mathrm{g} / \mathrm{mL}$; showed in this report $)$ of the recombinant Cry1Ia12 against $A$. grandis weevil was similar to the reported toxicity of Cryl Ia1 against the Colorado potato beetle larvae $(250 \mu \mathrm{g} / \mathrm{mL})$ (Tailor et al., 1992), which reflects a moderate insecticidal activity under the tested conditions.

Since the first report from almost 20 years ago of a Cry protein toxic to $A$. grandis (Herrnstadt et al., 1986), no transgenic plant resistant to boll weevil was ever reported, although this Coleoptera insect-pest is economically important in cotton crop in different producer countries, being the most devastating cotton insect pest in Brazil. The commercially available $B t$ transgenic cotton event Bollgard II (Monsanto) expresses Cry1 Ac/Cry1 Ab and Cry2Aa toxins that confers mild resistance against $S$. frugiperda (Hamilton et al., 2004), and no confer resistance towards $A$. grandis. Our finding shows that the recombinant Cry1Ia12 protein is moderately toxic to the cotton boll weevil, besides being toxic to cotton fall armyworm in bioassays; opens, thus, promising perspectives to obtain Cry transgenic cotton lines resistant to both these devastating cotton pests.

It has been reported that several insect pests have developed resistance against insecticidal Cry proteins (Tabashnik et al., 1993, 1997; Ferre and Van Rie, 2002). To avoid the development of resistance by insects to $B t$ toxins, it is important to use stacked gene strategy, which consists of a combination of cry genes and/or other genes encoding insecticidal proteins within the same transgenic crop (Ferre and Van Rye, 2002; Christou et al., 2006). However, one requirement for the stacked gene strategy to be efficient is that the stacked Cry toxins bind to different receptors within the target insect gut epithelium. Estela et al. (2004) showed that Cry1Ac and Cry1Ab toxins use different epitopes for binding gut brush border membrane vesicles of the Lepidoptera Helicoverpa armigera, making these cry genes appropriate to compose a stacked gene strategy for cotton insect resistance. Therefore, isolation of novel cry genes, such as the presently described cryllal2 gene, encoding proteins with presumable distinct modes of action against target cotton insect pests are crucial for pest control within cotton crop.

It will be interesting to test the toxicity spectrum of Cry1Ia12 against Coleopteran and Lepidopteran other than A. grandis and $S$. frugiperda. Also, it is important to test its toxicity even against nematodes that attack the cotton crop. Studies on the effect of the microbial flora present in the midgut of target insect larvae (Broderick et al., 2006) on the toxicity of Cry1Ia12, studies on midgut receptors for Cry1Ia12 and studies on sequence mutagenesis impacts on the toxicity of Cry1Ia12 would definitely contribute to elucidate why Cry1Ia12 is less toxic to cotton boll weevil larvae than it is to fall armyworm larvae. Moreover, the crylIal 2 can be used as a DNA shuffling parental gene to generate $c r y$ genes with optimized and enhanced activity against important cotton pests. In conclusion, the insecticidal activity of Cry1Ia12 against $A$. grandis and $S$. frugiperda, and potentially against other relevant cotton pests, may prove to be valuable for transgenic control strategies, supported by beforehand meticulous bio-safety studies (Andow et al., 2006), in field conditions.

Acknowledgments We are thankful to the laboratory of Biological Control at EMBRAPA Genetic Resources and Biotechnology for providing the Bt strain S811 and for suppling the $A$. grandis and $S$. frugiperda larvae. This work was supported by EMBRAPA, CAPES, CNPq, FACUAL and FIALGO-Brazil. 


\section{References}

Andow, D. A., Lövei, G. L. and Arpaia, S. (2006) Ecological risk assessment for Bt crops. Nat. Biotechnol. 24, 749-751.

Betz, F. S., Hammond, B. G. and Fuchs, R. L. (2000) Safety and advantages of Bacillus thuringiensis-protected plants to control insect pests. Regul. Toxicol. Pharmacol. 32, 156-173.

Bravo, A., Sarabia, S., Lopez, L., Ontiveros, H., Abarca, C., Ortiz, A., Ortiz, M., Lina, L., Villalobos, F. J. and Pena, G. (1998) Characterization of cry genes in a Mexican Bacillus thuringiensis strain collection. Appl. Environ. Microbiol. 64, 4965-4972.

Broderick, N. A., Raffa, K. F. and Handelsman, J. (2006) Midgut bacteria required for Bacillus thuringiensis insecticidal activity. Proc. Natl. Acad. Sci. 103, 151-196.

Ceron, J., Ortiz, A., Quintero, R., Guereca, L. and Bravo, A. (1995) Specific PCR primers directed to identify cryI and cryII genes within a Bacillus thuringiensis strain collection. Appl. Environ. Microbiol. 61, 3826-3831.

Chattopadhyay, A., Bhatnagar, N. B. and Bhatnagar , R. (2004) Bacterial insecticidal toxins. Crit. Rev. Microbiol. 30, 33-54.

Christou, P., Capell, T., Kohli, A., Gatehouse, J. A. and Gatehouse, A. M. (2006) Recent developments and future prospects in insect pest control in transgenic crops. Trends Plant Sci. 11, 302-308.

Choi, S. K., Shin, B. S., Kong, E. M., Rho, H. M. and Park, S. H. (2000). Cloning of a new Bacillus thuringiensis CrylI-type crystal protein. Curr. Microbiol. 41, 65-69.

Crickmore, N., Zeigler, D. R., Feitelson, J., Schnepf, E., Van Rie, J., Lereclus, D., Baum, J. and Dean, D. H. (1998) Revision of the nomenclature for the Bacillus thuringiensis pesticidal crystal proteins. Microbiol. Mol. Biol. Rev. 62, 807-813.

de Maagd, R. A., Bravo, A. and Crickmore, N. (2001) How Bacillus thuringiensis has evolved specific toxins to colonize the insect world. Trends Genet. 17, 193-199.

de Maagd, R. A., Bravo, A., Berry, C., Crickmore, N. and Schnepf, H. E. (2003) Structure, diversity, and evolution of protein toxins from spore-forming entomopathogenic bacteria. Аnпu. Rev. Genet. 37, 409-433.

Donovan, W. P., Donovan, J. C. and Slaney, A. C. (2000) Bacillus thuringiensis CryET33 and CryET34 proteins - having activity against Coleoptera insects, particularly boll weevil, red flour beetle and Japanese beetle. U.S. Patent Number US2006051822A1.

Doyle, J. J. and Doyle, J. L. (1987) A rapid DNA isolation procedure for small quantities of fresh leaf tissue. Phytochemical Bulletin 19, 11-15.

Estela, A., Escriche, B. and Ferre, J. (2004) Interaction of Bacillus thuringiensis toxins with larval midgut binding sites of Helicoverpa armigera (Lepidoptera: Noctuidae). Appl. Environ. Microbiol. 70, 1378-1384.

Ferre, J. and Van Rie, J. (2002) Biochemistry and genetics of insect resistance to Bacillus thuringiensis. Annu. Rev. Entomol. 47, 501-533.

Gleave, A. P., Williams, R. and Hedges, R. J. (1993) Screening by polymerase chain reaction of Bacillus thuringiensis serotypes for the presence of CryV-like insecticidal protein genes and characterization of a cryV gene cloned from Bacillus thuringiensis subsp kurstaki. Appl. Environ. Microbiol. 59, 1683-1687.

Hamilton, K. A., Pyla, P. D., Breeze, M., Olson, T., Li, M.,
Robinson, E., Gallagher, S. P., Sorbet, R. and Chen, Y. (2004) Bollgard II cotton: compositional analysis and feeding studies of cottonseed from insect-protected cotton (Gossypium hirsutum L.) producing the Cry $1 \mathrm{Ac}$ and $\mathrm{Cry} 2 \mathrm{Ab} 2$ proteins. J. Agric. Food Chem. 52, 6969-6976.

Haynes, J. W. and Smith, J. W. (1992) Longevity of laboratoryreared boll-weevils (Coleoptera, Curculionidae) offered honey bee-collected pollen and plants unrelated to cotton. J. Entomol. Sci. 27, 366-374.

He, K. L., Wang, Z. Y., Zhou, D. R., Wen, L. P., Song, Y. Y. and Yao, Z. Y. (2003) Evaluation of transgenic Bt corn for resistance to the Asian corn borer (Lepidoptera: Pyralidae). $J$. Econ. Entomol. 96, 935-940.

Herrnstadt, C., Soares, G. G., Wilcox, E. R. and Edwards, D. L. (1986) A new strain of Bacillus-thuringiensis with activity against coleopteran insects. Bio-Technology 4, 305-308.

Hilder, V. A. and Boulter, D. (1999) Genetic engineering of crop plants for insect resistance - a critical review. Crop Prot. 18, 177-191.

Hofmann, C., Vanderbruggen, H., Hofte, H., Van Rie, J., Jansens, S. and Van Mellaert, H. (1988) Specificity of Bacillus thuringiensis delta-endotoxins is correlated with the presence of high-affinity binding sites in the brush border membrane of target insect midguts. PNAS 85, 7844-7848.

Knowles, B. (1994) Mechanism of action of Bacillus thuringiensis insecticidal d-endotoxins. Adv. Insect Physiol. 24, 275-308.

Koo, B. T., Park, S. H., Choi, S. K. Shin, B. S., Kim, J. I. and Yu, J. H. (1995) Cloning of a novel crystal protein gene Crylk from Bacillus thuringiensis subsp Morrisoni. FEMS Microbiol. Lett. 134, 159-164.

Kostichka, K., Warren, G. W., Mullins, M., Mullins, A. D., Craig, J. A., Koziel, M. G. and Estruch, J. J. (1996) Cloning of a CryV-type insecticidal protein gene from Bacillus thuringiensis: the CryV-encoded protein is expressed early in stationary phase. J. Bacteriol. 178, 2141-2144.

Laemmli, U. K. (1970) Cleavage of structural proteins during assembly of head of Bacteriophage-T4. Nature 227, 680-685.

Liu, K. Y., Zheng, B. L., Hong, H. Z., Jiang, C. F., Peng, R., Peng, J. X., Yu, Z. H., Zheng, J. and Yang, H. (2004) Characterization of cultured insect cells selected by Bacillus thuringiensis crystal toxin. In Vitro Cell. Dev. Biol. Anim. 40, 312-317.

Lowry, O. H., Rosebrough, N. J., Farr, A. L. and Randal, R. J. (1951) Protein measurement with the folin phenol reagent. $J$. Biol. Chem. 193, 265-275.

Martins, E. S. (2005a) Clonagem, expressão e análise da patalogia de proteínas Cry, derivadas de Bacillus thuringiensis, em insetos-praga. Master Degree Dissertation, Universidade de Brasília, Brasília, Brazil.

Martins, E., Praça, L., Dumas, V., Sone, E., Waga, I., Gomes, A. C. M., Falcao, R. and Monnerat, R. G. (2005b) Caracterização de estirpes de Bacillus thuringiensis tóxicas ao bicudo do algodoeiro. Boletim de Pesquisa e Desenvolvimento Embrapa 83, 1-19.

Monnerat, R. G. D., Oliveira-Neto, O. B., Nobre, S. D., SilvaWerneck, J. O. and Grossi de Sa, M. F. (2000) Criação massal do bicudo do algodoeiro Anthonomus grandis em laboratório. Comunicado Técnico/ Embrapa 46, 1-4.

Praça, L. B., Batista, A. C., Martins, E. S., Siqueira, C. B., Dias, D. G. D., Gomes, A. C. M. M., Falcao, R. and Monnerat, R. 
G. (2004) Bacillus thuringiensis strains effective against insects of Lepidoptera, Coleoptera and Diptera orders. Pesqui. Agropecu. Bras. 39, 11-16.

Quezado, M. (2006) Toxinas cry: perspectivas para obtenção de algodão transgênico brasileiro. Master Degree Dissertation. Universidade Federal do Rio Grande do Sul, Porto Alegre, Brazil.

Sambrook, J. and Russel, D. W. (2001) Molecular Cloning - $A$ Laboratory Manual, $3^{\text {rd }}$ ed., Cold Spring Laboratory Press, New York, USA.

Sasaki, J., Asano, S., Iizuka, T., Bando, H., Lay, B. W., Hastowo, S., Powell, G. K. and Yamamoto, T. (1996) Insecticidal activity of the protein encoded by the cryV gene of Bacillus thuringiensis kurstaki INA-02. Curr. Microbiol. 32, 195-200.

Schwartz, J. L., Garneau, L., Savaria, D., Masson, L., Brousseau, R. and Rousseau, E. (1993) Lepidopteran-specific crystal toxins from Bacillus thuringiensis form cation- and anion-selective channels in planar lipid bilayers. J. Membr. Biol. 132, 53-62.

Schnepf, E., Crickmore, N., Van Rie, J., Lereclus, D., Baum, J., Feitelson, J., Zeigler, D. and Dean, D. (1998) Bacillus thuringiensis and its pesticidal crystal proteins. Microbiol. Mol. Biol. Rev. 62, 775-806.

Sekar, V., Held, B., Tippett, J., Amirhusin, B., Robeff, P., Wang, K. and Wilson, H. M. (1997) Biochemical and molecular characterization of the insecticidal fragment of CryV. Appl. Environ. Microbiol. 63, 2798-2801.

Selvapandiyan, A., Reddy, V. S., Kumar, P., Tewari, K. K. and Bhatnagar, R. K. (1998) Transformation of Nicotiana tabacum with a native crylla5 gene confers complete protection against Heliothis armigera. Molecular Breeding 4, 473-478.

Shin, B. S., Park, S. H., Choi, S. K., Koo, B. T., Lee, S. T. and Kim J. I. (1995) Distribution of CryV-type insecticidal protein genes in Bacillus-thuringiensis and cloning of cryY-type genes from Bacillus-thuringiensis Subsp kurstaki and Bacillusthuringiensis Subsp entomocidus. Appl. Environ. Microbiol. 61, 2402-2407.

Song, F. P., Zhang, J., Gu, A. X., Wu, Y., Han, L. L., He, K. L., Chen, Z. Y., Yao, J., Hu, Y. Q., Li, G. X. and Huang, D. F. (2003) Identification of cryll-type genes from Bacillus thuringiensis strains and characterization of a novel cryll-type gene. Appl. Environ. Microbiol. 69, 5207-5211.

Tabashnik, B. E., Finson, N., Johnson, M. W. and Moar, W. J. (1993) Resistance to toxin from Bacillus thuringiensis sbsp. kurstaki causes minimal cross-resistance to $B$. thuringiensis subsp. aizawai in the diamondback moth Lepidopetera: Plutellida. Appl. Environ. Microbiol. 59, 1332-1335.

Tabashnik, B. E., T. Malvar, Y. B. Liu, N. Finson, D. Borthakur, B. Y. S. Shin, S. H. Park, L. Masson, R. A. de Maagd, and D. Bosch. (1996) Cross-resistance of the diamondback moth indicates altered interactions with domain II of Bacillus thuringiensis toxins. Appl. Environ. Microbiol. 62, 2839-2844.

Tabashnik, B. E., Liu, Y. B., Malvar, T., Heckel, D. G., Masson, L., Ballester, V. Granero, F., Mensua, J. L. and Ferre, J. (1997) Global variation in the genetic and biochemical basis of diamondback moth resistance to Bacillus thuringiensis. PNAS. 94, 12780-12785.

Tailor, R., Tippett, J., Gibb, G., Pells, S., Pike, D., Jordan, L. and Ely, S. (1992) Identification and characterization of a novel Bacillus thuringiensis delta-endotoxin entomocidal to coleopteran and lepidopteran larvae. Mol. Microbiol. 6, 1211-1217.

Van Rie, J. (2000) Bacillus thuringiensis and its use in transgenic insect control technologiies. Int. J. Med. Microbiol. 290, 463469. 